\title{
Mirosław Karpiuk
}

Uniwersytet Warmińsko-Mazurski w Olsztynie

m_karpiuk@wp.pl

\section{Przepisy porządkowe jako szczególny rodzaj prawa miejscowego}

\author{
Regulations as a Special Type of Local Law
}

\section{STRESZCZENIE}

Przepisy porządkowe należą do katalogu źródeł prawa powszechnie obowiązującego, władczo kształtując status adresata. Zakres obowiązywania przepisów porządkowych, ustanawianych w ramach prawa miejscowego, dotyczy obszaru, na który rozciąga się właściwość organu ustanawiającego taki akt. Powyższe przepisy mają charakter wykonawczy, upoważnienie do ich wydania musi być zawarte w ustawie. Organ administracji publicznej nie może zatem kształtować statusu prawnego adresata, gdy ustawodawca na to mu nie pozwala.

Słowa kluczowe: źródła prawa powszechnie obowiązującego; organ administracji publicznej

\section{WSTĘP}

Jedną z form działania administracji publicznej są akty prawa miejscowego stanowiące źródło prawa powszechnie obowiązującego, w ramach których można wyróżnić przepisy porządkowe. Upoważnienie do działania w tej formie prawnej przyznano administracji terenowej, co dotyczy zarówno samorządu terytorialnego, jak i administracji rządowej. Ze względu na zakres oddziaływania przepisów porządkowych na status podmiotów zewnętrznych muszą one być ustanawiane wyłącznie dla ochrony kwalifikowanego interesu. Ich stopień dolegliwości dla adresata determinuje stosowanie tego rodzaju norm dopiero w ostateczności, gdy inne środki prawne nie są w stanie należycie zabezpieczyć ważnego interesu.

Przepisy porządkowe, podobnie jak inne akty prawa miejscowego, muszą być wydawane na podstawie i w granicach zakreślonych przez ustawodawcę. Organy terenowej administracji publicznej muszą zatem posiadać legitymację ustawową 
do ingerowania $\mathrm{w}$ sferę adresata $\mathrm{w}$ drodze aktu prawa miejscowego zawierającego przepisy porządkowe. $\mathrm{W}$ tym zakresie nie obowiązuje domniemanie i nie może być stosowana wykładnia rozszerzająca.

\section{KONSTYTUCYJNE PODSTAWY STANOWIENIA PRZEPISÓW PORZĄDKOWYCH}

Ustrojodawca aktom prawa miejscowego, w tym przepisom porządkowym, przyznaje status źródeł prawa powszechnie obowiązującego, stanowiąc, że źródłami powszechnie obowiązującego prawa Rzeczypospolitej Polskiej są na obszarze działania organów, które je ustanowiły, akty prawa miejscowego ${ }^{1}$. Przestrzenne obowiązywanie przepisów porządkowych, według Konstytucji RP, obejmuje obszar działania organów je ustanawiających. Zasada ta może mieć jednak ograniczone zastosowanie, gdy właściwość miejscowa organu ustanawiającego przepisy porządkowe zostanie zmieniona $\mathrm{w}$ trakcie jego obowiązywania.

Organy samorządu terytorialnego oraz terenowe organy administracji rządowej, na podstawie i w granicach upoważnień zawartych w ustawie, ustanawiają akty prawa miejscowego, które obowiązują na obszarze działania tych organów, o czym stanowi art. 94 Konstytucji RP². Przepis ten ogólnie określa, kto w terenie może stanowić akty prawa miejscowego (przepisy porządkowe). Mówi o: 1) organach samorządu terytorialnego, nie wskazując, o jakie organy chodzi; 2) terenowych organach administracji rządowej, również nie dookreślając, jakie organy (zespolone, niezespolone) ma na uwadze. Ustrojodawca w związku z powyższym kwestie właściwości podmiotowej w zakresie stanowienia przepisów porządkowych pozostawia do uregulowania ustawodawcy zwykłemu.

Przepisy porządkowe stanowione są na podstawie oraz w granicach upoważnień ustawowych. Ustawodawca może zatem zdecydować, że określona sfera zostanie uregulowana $\mathrm{w}$ drodze przepisów porządkowych.

Akt normatywny, który został wydany z przekroczeniem granic upoważnienia ustawowego, nie spełnia konstytucyjnych przesłanek legalności aktu wykonawczego, w związku z czym jest on niezgodny z art. 2 Konstytucji RP, ponieważ w demokratycznym państwie prawnym nie może funkcjonować akt prawny o charakterze podustawowym, sprzeczny z przepisami ustawowymi przez to, że został wydany przez organ władzy wykonawczej z przekroczeniem delegacji ustawowej

${ }^{1}$ Art. 87 ust. 2 Konstytucji Rzeczypospolitej Polskiej z dnia 2 kwietnia 1997 roku (Dz.U., nr 78, poz. 483 ze zm.), dalej: Konstytucja RP. Konstytucja RP nie określa cech aktów prawa miejscowego. Zob. B. Banaszak, Konstytucja Rzeczypospolitej Polskiej. Komentarz, Warszawa 2009, s. 442.

${ }^{2}$ Art. 94 Konstytucji RP nie posługuje się nazwami rodzajowymi aktów prawa miejscowego. Zob. P. Winczorek, Komentarz do Konstytucji Rzeczypospolitej Polskiej z dnia 2 kwietnia 1997 roku, Warszawa 2008, s. 219. 
do jego wydania ${ }^{3}$. Akt prawa miejscowego organu jednostki samorządu terytorialnego (w tym również zawierający przepisy porządkowe) stanowiony jest na podstawie upoważnienia ustawowego, powinien być sporządzony tak, aby jego regulacja nie wykraczała poza jakiekolwiek unormowania ustawowe, nie czyniła wyjątków od ogólnie przyjętych rozwiązań ustawowych oraz aby nie powtarzała kwestii uregulowanych w aktach prawnych hierarchicznie wyższych. Musi zawierać sformułowania jasne, wyczerpujące, uniemożliwiające stosowanie niedopuszczalnego, sprzecznego z prawem luzu interpretacyjnego ${ }^{4}$.

Konstytucja RP w art. 31 ust. 3 stanowi, że ograniczenia w zakresie korzystania z konstytucyjnych wolności i praw mogą być ustanawiane tylko w ustawie i tylko wtedy, gdy są konieczne w demokratycznym państwie dla jego bezpieczeństwa lub porządku publicznego, jak również dla ochrony środowiska, zdrowia i moralności publicznej albo wolności i praw innych osób. Powyższe ograniczenia nie mogą naruszać istoty wolności i praw. Ustrojodawca jako formę prawną ograniczenia korzystania z konstytucyjnych wolności i praw przewiduje ustawę, posługując się zwrotem „tylko w ustawie” odnośnie do możliwości wprowadzenia tego rodzaju ograniczenia. Drugą niezbędną przesłanką dopuszczającą ograniczenie konstytucyjnych wolności i praw jest konieczność ochrony oczywiście ważniejszego interesu publicznego wskazanego w art. 31 ust. 3 Konstytucji RP.

Konstytucja RP w art. 31 ust. 3 formułuje kumulatywnie ujęte przesłanki dopuszczalności ograniczeń korzystania z konstytucyjnych praw i wolności, do których należą: ustawowa forma ograniczenia, istnienie w państwie demokratycznym konieczności wprowadzenia ograniczenia, funkcjonalny związek ograniczenia $\mathrm{z}$ realizacją wskazanych $\mathrm{w}$ tym przepisie wartości (bezpieczeństwo państwa, porządek publiczny, ochrona środowiska, zdrowia i moralności publicznej, wolności i praw innych osób) oraz zakaz naruszania istoty danego prawa lub wolności ${ }^{5}$.

Stwierdzenie przez ustrojodawcę, że ograniczenia mogą być ustanawiane tylko wtedy, gdy są konieczne w demokratycznym państwie, nakazuje rozważyć, czy wprowadzona przez ustawodawcę regulacja jest w stanie doprowadzić do zamierzonych przez nią skutków, jak również czy ta regulacja jest niezbędna dla

${ }^{3}$ Wyrok WSA z dnia 21 marca 2012 roku, IV SA/Wr 743/11, LEX nr 1139685.

${ }^{4}$ Wyrok WSA z dnia 24 stycznia 2012 roku, II SA/Wr 786/11, LEX nr 1114101. Podejmując akty prawa miejscowego na podstawie normy ustawowej, organ stanowiący musi ściśle uwzględniać wytyczne zawarte w upoważnieniu. Odstąpienie od powyższej zasady narusza związek formalny, jak również materialny pomiędzy aktem wykonawczym a ustawą, co z zasady stanowi istotne naruszenie prawa. Naczelną zasadą prawa administracyjnego jest zakaz domniemania kompetencji, a z kolei normy kompetencyjne powinny być interpretowane w sposób ścisły, literalny. Nie można również dokonywać wykładni rozszerzającej przepisów kompetencyjnych oraz wyprowadzania kompetencji w drodze analogii. Wyrok WSA z dnia 11 maja 2011 roku, II SA/Gd 244/11, LEX nr 795646.

${ }^{5}$ Wyrok TK z dnia 24 marca 2003 roku, P 14/01, OTK ZU 2003, nr 3A, poz. 22; wyrok TK z dnia 6 marca 2007 roku, SK 54/06, OTK ZU 2007, nr 3A, poz. 23. 
ochrony interesu publicznego, z którym jest związana oraz czy efekty wprowadzonej regulacji pozostają $\mathrm{w}$ odpowiedniej proporcji do ciężarów nakładanych przez nią na obywatela ${ }^{6}$.

W art. 31 ust. 3 Konstytucji RP określa się granice ingerencji w gwarantowane konstytucyjnie prawa i wolności. Ich ograniczenie może nastąpić, w myśl zasady proporcjonalności, wyłącznie jeżeli jest konieczne w demokratycznym państwie, i to ze względu na jedną ze ściśle określonych przesłanek bądź kilka z nich, takich jak bezpieczeństwo państwa, porządek publiczny czy ochrona zdrowia i moralności publicznej, wolności i praw innych osób. Każda regulacja, która ingeruje w konstytucyjne wolności lub prawa powinna przejść „test proporcjonalności”, co powoduje, że ustanowienie ograniczenia musi zostać poprzedzone analizą: czy projektowana regulacja może spowodować osiągnięcie zamierzonego celu, czy jest niezbędna z punktu widzenia ochrony wymienionych w art. 31 ust. 3 Konstytucji RP wartości oraz czy efekty regulacji są proporcjonalne do ciężarów nakładanych na obywateli. Istotą zasady proporcjonalności jest zakaz nadmiernej ingerencji ustawodawcy, który jest oceniany przez pryzmat możliwości osiągnięcia takiego samego efektu za pomocą środków w mniejszym stopniu ograniczających korzystanie z konstytucyjnych wolności lub praw. Ustanawiając ograniczenia, ustawodawca nie powinien przekraczać pewnego stopnia uciążliwości, a w szczególności prowadzić do zaburzenia proporcji pomiędzy stopniem naruszenia uprawnień jednostki a rangą interesu publicznego podlegającego $\mathrm{w}$ danym przypadku ochronie ${ }^{7}$.

Przepisy porządkowe nie mogą, w myśl art. 31 ust. 3 Konstytucji RP, wkraczać w sferę korzystania z konstytucyjnych wolności i praw, ograniczając je. Tego rodzaju możliwość ingerencyjna przewidziana jest wyłącznie dla ustawodawcy. Istotą przepisów porządkowych jest jednak ograniczanie wolności i praw zagwarantowanych w Konstytucji RP, co ma następować w szczególnie uzasadnionych sytuacjach. Reagowanie przez terenowe organy administracji rządowej w drodze przepisów porządkowych na zagrożenie o charakterze kwalifikowanym przez ingerencję w sferę wolności i praw człowieka i obywatela jest jednak dopuszczone przez ustawodawcę, co należy uznać za niedopuszczalne i sprzeczne z Konstytucją RP. „Ograniczenia w zakresie korzystania z konstytucyjnych wolności i praw mogą być ustanawiane tylko w ustawie", nie dopuszcza się więc ograniczeń tej sfery $\mathrm{w}$ formie aktu podstawowego.

Trybunał Konstytucyjny stoi jednak na stanowisku, że konstytucyjna zasada wyłączności ustawy nie wyklucza powierzenia przez ustawę właściwym organom ogólnej kompetencji do stanowienia w akcie prawa miejscowego unormowań prawnych mających na celu przeciwdziałanie zagrożeniom dla życia, zdrowia lub

${ }^{6}$ Wyrok TK z dnia 28 czerwca 2000 roku, K 34/99, OTK ZU 2000, nr 5, poz. 142; wyrok TK z dnia 24 marca 2003 roku, P 14/01, OTK ZU 2003, nr 3A, poz. 22.

${ }^{7}$ Wyrok TK z dnia 8 kwietnia 2014 roku, SK 22/11, OTK ZU 2014, nr 4A, poz. 37. 
mienia, jak również dla spokoju publicznego, pod warunkiem, że regulacje te są zgodne z zasadą proporcjonalności i nie jest możliwe skuteczne przeciwdziałanie tym zagrożeniom na gruncie istniejących uregulowań ustawowych ${ }^{8}$. Wydaje się, że w świetle tego stanowiska zwrot „tylko w ustawie”, którym posługuje się Konstytucja RP w art. 31 ust. 3, jest na tyle „nieostry”, że nie należy stosować wykładni językowej, gdyż „tylko w ustawie” należy również interpretować jako „nie tylko w ustawie”, chociaż to stanowisko nie wydaje się, by miało oparcie w powyższym przepisie.

\section{STANOWIENIE PRZEPISÓW PORZĄDKOWYCH PRZEZ ORGANY ADMINISTRACJI RZĄDOWEJ}

W zakresie nieuregulowanym $\mathrm{w}$ przepisach powszechnie obowiązujących wojewoda może wydawać rozporządzenia porządkowe w przypadku, gdy jest to niezbędne do ochrony życia, zdrowia lub mienia, jak również do zapewnienia porządku, spokoju i bezpieczeństwa publicznego'. Ustawodawca w tym przepisie wskazuje na uprawnienie wojewody, a nie na jego obowiązek, używając pojęcia „może” odnośnie do wydawania rozporządzeń porządkowych. Nie wydaje się jednak, żeby konieczność zapewnienia bezpieczeństwa czy zachowania innych istotnych wartości pozostawały w sferze uznania wojewody. W przypadku kwalifikowanego zagrożenia dla ważnych interesów wojewoda powinien reagować, aby mu zapobiec bądź przeciwdziałać rozprzestrzenianiu się jego skutków, a także te skutki usuwać, w tym w formie rozporządzeń porządkowych, o ile zachodzi taka konieczność. Ustawodawca nie nakłada takiego obowiązku, posługując się zwrotem „może”, zatem rozstrzygnięcie w tym zakresie pozostawia uznaniu wojewody, chociaż celem regulacji jest zabezpieczenie dóbr określonych w art. 60 ust. 1 u.w.a.r., a nie „ewentualne” ich zabezpieczenie.

Do przesłanek uzasadniających wydanie rozporządzenia porządkowego należą: ochrona życia, zdrowia lub mienia, zapewnienie porządku, spokoju i bezpieczeństwa publicznego. Ustawodawca unika zbędnej kazuistyki, aby nie pominąć w ramach tych wartości aspektów, które powinny podlegać ochronie. Określa je w sposób ogólny, nie dając wskazówek, co rozumie przez te pojęcia. Pomimo że niebezpieczne jest nadmierne dookreślenie tego rodzaju przesłanek, może to spowodować wyłączenie spod ochrony tych sfer, które ochronie powinny podlegać, to jednak z drugiej strony ich nieostrość może spowodować nieuzasadnioną

\footnotetext{
${ }^{8}$ Wyrok TK z dnia 8 lipca 2003 roku, P 10/02, OTK ZU 2003, nr 6A, poz. 62.

${ }^{9}$ Art. 60 ust. 1 ustawy z dnia 23 stycznia 2009 roku o wojewodzie i administracji rządowej w województwie (Dz.U., nr 31, poz. 206 ze zm.), dalej: u.w.a.r. Zob. także: K. Walczuk, [w:] Ustawa o wojewodzie i administracji rzadowej w województwie. Komentarz, pod red. M. Czuryk, M. Karpiuka, M. Mazuryka, Warszawa 2012, s. 161-165.
} 
uznaniowość i wkraczanie w tę przestrzeń, w granicach której ingerencja jest niedozwolona.

W świetle art. 60 ust. 2 u.w.a.r. rozporządzenia porządkowe wojewody mogą przewidywać - za naruszenie ich przepisów - kary grzywny. Sankcją za naruszenie przepisów rozporządzenia porządkowego wydanego przez wojewodę w trybie art. 60 ust. 1 u.w.a.r. jest grzywna, przy czym art. 60 ust. 2 u.w.a.r. ma charakter odsyłający, nie reguluje samodzielnie kwestii wymierzania kary grzywny.

Grzywna, o której mówi art. 60 ust. 2 u.w.a.r., wymierzana jest w wysokości od 20 do 5000 złotych. Wymierzając karę grzywny, bierze się pod uwagę dochody sprawcy, jego warunki osobiste i rodzinne, stosunki majątkowe oraz możliwości zarobkowe ${ }^{10}$. Według art. 54 k.w., kto wykracza przeciwko wydanym z ustawowego upoważnienia przepisom porządkowym o zachowaniu się w miejscach publicznych, podlega karze grzywny do 500 złotych albo karze nagany.

Odesłanie, które jest zawarte w art. 54 k.w., obejmuje tylko przepisy porządkowe. Termin ten nie został zdefiniowany w obowiązującym ustawodawstwie, precyzyjne ustalenie jego znaczenia może budzić wątpliwości. W praktyce ustawy udzielające upoważnień do stanowienia przepisów porządkowych wyraźnie kwalifikują te przepisy przy pomocy terminów: ,przepisy porządkowe”, „rozporządzenia porządkowe” czy „zarządzenia porządkowe”. W przypadku ustaw niezawierających takiego określenia mogłyby jednak powstawać wątpliwości, czy dany akt normatywny mieści się w kategorii „przepisów porządkowych”. Norma ta zawiera odesłanie do przepisów porządkowych wydawanych w celu zapewnienia porządku i spokoju publicznego. W konsekwencji, w przypadku naruszenia przepisów, które mają inny przedmiot ochrony, nie jest możliwe zastosowanie art. 54 k.w. Należy zauważyć, że podstawę karania w tym przypadku może stanowić wyłącznie naruszenie przepisów regulujących zachowanie w miejscach publicznych. Brzmienie art. 54 k.w. nie pozwala samo w sobie adresatowi zorientować się co do treści ustanowionego zakazu lub nakazu. Z zaskarżonego przepisu adresat może tylko wyciągnąć wniosek, że ma obowiązek przestrzegania pewnych zasad, które mają zapewnić ochronę porządku publicznego w miejscach publicznych, zasad skonkretyzowanych w przepisach podustawowych ${ }^{11}$.

Przy tworzeniu przepisów porządkowych, mających wypełniać swoją treścią dyspozycję przepisu o charakterze „blankietowym”, zawierającego określoną sankcję (np. art. 54 k.w.), wystarczające będzie ogólne odesłanie do odpowiedzialności przewidzianej w tym przepisie ${ }^{12}$.

Rozporządzenia porządkowe wojewoda przekazuje niezwłocznie Prezesowi Rady Ministrów, marszałkowi województwa, starostom, prezydentom miast,

${ }^{10}$ Art. 24 ustawy z dnia 20 maja 1971 roku - Kodeks wykroczeń (t.j. Dz.U. z 2013 roku, poz. 482 ze zm.), dalej: k.w.

${ }^{11}$ Wyrok TK z dnia 8 lipca 2003 roku, P 10/02, OTK ZU 2003, nr 6A, poz. 62.

${ }^{12}$ Wyrok SN z dnia 9 czerwca 2005 roku, V KK 41/05, OSNKW 2005, nr 9, poz. 83. 
burmistrzom i wójtom, na których terenie rozporządzenie ma być stosowane, co czyni na podstawie art. 60 ust. 3 u.w.a.r. Na wojewodę został nałożony obowiązek przekazywania przepisów porządkowych enumeratywnie wymienionym $\mathrm{w}$ art. 60 ust. 3 u.w.a.r. organom. Powyższe wynika $z$ ewentualnego zastosowania szybkiej ścieżki nadzoru - Prezes RM, jak również z potrzeby niezwłocznego zapoznania się z treścią nakazów i podjęcia stosownych działań (np. dalszego upublicznienia, niewydawania przepisów kolizyjnych) - organy samorządu terytorialnego. Przy czym należy przyjąć, że w art. 60 ust. 3 u.w.a.r. chodzi nie tylko o rozporządzenia porządkowe, ale i o przepisy porządkowe. Jeżeli zatem w zarządzeniu, jako akcie prawa miejscowego, znajdą się jakieś przepisy porządkowe, to powinny też podlegać obowiązkowi przekazania właściwym organom, określonemu w art. 60 ust. 3 u.w.a.r.

Rozporządzenia porządkowe zaliczane są do najmniej jednolitej, jak również budzącej szereg wątpliwości natury prawnej kategorii źródeł prawa, jaką są akty prawa miejscowego. Są przy tym aktami prawnymi, które z zasady dotyczą bardzo wrażliwych sfer życia obywateli ${ }^{13}$.

W zakresie nieunormowanym w przepisach powszechnie obowiązujących, w przypadku gdy jest to niezbędne do ochrony życia, zdrowia lub mienia, ochrony środowiska morskiego na morzu, w porcie morskim, przystani oraz w pasie technicznym, jak również dla ochrony żeglugi i portów morskich - dyrektor urzędu morskiego może ustanawiać przepisy porządkowe zawierające zakazy lub nakazy określonego zachowania się. Ustanawia je w formie zarządzenia porządkowego. Zarządzenie porządkowe wchodzi w życie z dniem w nim określonym, nie wcześniej jednak niż z dniem jego ogłoszenia. Podlega ono ogłoszeniu w wojewódzkim dzienniku urzędowym właściwym ze względu na terytorialny zakres obowiązywania tego zarządzenia. W przypadku zaistnienia konieczności natychmiastowego wprowadzenia w życie zarządzenia porządkowego, może ono być publikowane w drodze obwieszczeń w miejscach jego obowiązywania, drogą radiową lub w inny sposób zwyczajowo przyjęty w żegludze morskiej lub na danym terenie, a następnie podaje się go do wiadomości we właściwym wojewódzkim dzienniku urzędowym. Dzień opublikowania takiego zarządzenia porządkowego jest dniem jego ogłoszenia ${ }^{14}$. Kompetencję do stanowienia przepisów porząd-

${ }^{13}$ K. Walczuk, Rozporzadzenie porządkowe jako akt prawa miejscowego, [w:] Tworzenie a stosowanie prawa w Polsce. Teoria i praktyka, pod red. D. Kotłowskiego, M. Mazuryka, K. Sadowskiego, Warszawa 2014, s. 277.

${ }^{14}$ Art. 48 ustawy z dnia 21 marca 1991 roku o obszarach morskich Rzeczypospolitej Polskiej i administracji morskiej (t.j. Dz.U. z 2013 roku, poz. 934 ze zm.), dalej: u.o.m. Zob. także: M. Czuryk, Akty prawa miejscowego organów rządowej administracji niezespolonej, [w:] Niezespolona administracja rzadowa, pod red. M. Czuryk, M. Karpiuka, J. Kostrubca, Warszawa 2011, s. 266-267; M. Karpiuk, Działalność prawodawcza administracji rządowej, [w:] Akty normatywne i administracyjne, pod red. M. Karpiuka, Warszawa 2009, s. 85-86. 
kowych art. 48 u.o.m. przyznaje dyrektorowi urzędu morskiego. Skorzystanie z niej jest zdeterminowane (według ogólnie przyjętej reguły) brakiem właściwej regulacji w przepisach powszechnie obowiązujących (chociaż ustawodawca błędnie posługuje się jedynie zwrotem „w przepisach”) oraz koniecznością ochrony istotnych wartości. Za naruszenie przepisów porządkowych nie przewiduje się sankcji w postaci kary grzywny, dyrektor urzędu morskiego zatem nie może sam rozstrzygać w tym zakresie.

Ustanawianie przepisów porządkowych przez niezespolony organ administracji morskiej jest ograniczone jego właściwością wynikającą z art. 42 ust. 2 u.o.m. Poza granice wytyczone na gruncie tego przepisu dyrektor urzędu morskiego nie może wykraczać nawet w przypadku istnienia konieczności ochrony istotnego interesu.

Do katalogu organów rządowej administracji niezespolonej należą także okręgowi inspektorzy rybołówstwa morskiego ${ }^{15}$, których ustawodawca wyposażył w kompetencję prawodawczą w zakresie stanowienia przepisów porządkowych. Według art. 55 u.r. w zakresie nieuregulowanym w przepisach u.r., o ile jest to niezbędne do ochrony żywych zasobów morza i zachowania porządku przy połowach, okręgowi inspektorzy rybołówstwa morskiego mogą wydawać zarządzenia porządkowe zawierające zakazy lub nakazy określonego zachowania. Zarządzenia porządkowe mogą przewidywać, za naruszenie ich przepisów, kary grzywny wymierzane na zasadach oraz $\mathrm{w}$ trybie określonych w prawie o wykroczeniach ${ }^{16}$.

\section{STANOWIENIE PRZEPISÓW PORZĄDKOWYCH PRZEZ ORGANY SAMORZĄDU TERYTORIALNEGO}

W zakresie nieuregulowanym ustawowo lub w innych przepisach powszechnie obowiązujących rada gminy może wydawać przepisy porządkowe, o ile jest to niezbędne dla ochrony życia lub zdrowia obywateli oraz dla zapewnienia porządku, spokoju i bezpieczeństwa publicznego. Przepisy porządkowe mogą przewidywać za ich naruszanie karę grzywny ${ }^{17}$. Przyczyną uzasadniającą wydanie przepisów porządkowych jest stan choćby potencjalnego zagrożenia życia lub zdrowia

${ }^{15}$ Art. 50 pkt 2 ustawy z dnia 19 lutego 2004 roku o rybołówstwie (t.j. Dz.U. z 2014 roku, poz. 1592 ze zm.), dalej: u.r.

${ }^{16}$ Zob. także: M. Czuryk, Akty prawa miejscowego ..., s. 267-268; K. Sikora, Akty prawa miejscowego terenowych organów administracji rządowej, [w:] M. Karpiuk, J. Kostrubiec, M. Paździor, K. Popik-Chorąży, K. Sikora, Legislacja administracyjna, Warszawa 2013, s. 152-153.

${ }^{17}$ Art. 40 ust. 3-4 ustawy z dnia 8 marca 1990 roku o samorządzie gminnym (t.j. Dz.U. z 2013 roku, poz. 594 ze zm.), dalej: u.s.g. „Niezbędny”, jako pojęcie, którym posługuje się art. 40 ust. 3 u.s.g., to taki, bez którego nie można się obejść, koniecznie potrzebny, nieodzowny. Zob. wyrok WSA z dnia 8 grudnia 2010 roku, IV SA/Po 793/10, LEX nr 821207. 
obywateli, porządku, spokoju i bezpieczeństwa publicznego oraz konieczność wprowadzenia norm prawnych służących ochronie tych dóbr ${ }^{18}$.

Wydanie przez radę gminy przepisów porządkowych jest zdeterminowane kumulatywnym zaistnieniem dwóch przesłanek, brakiem stosownej regulacji w przepisach powszechnie obowiązujących oraz koniecznością ochrony szczególnie ważnych wartości, do których należą: życie lub zdrowie obywateli, porządek, spokój, bezpieczeństwo publiczne. Rada gminy wydaje przepisy porządkowe w formie uchwały, bez konieczności procedowania w szczególnym trybie.

$\mathrm{Z}$ analizy art. 40 ust. 3 u.s.g. wynika, że aby wprowadzić określone normy w formie przepisów porządkowych, muszą wystąpić jednocześnie dwa warunki. Po pierwsze, materia podlegająca unormowaniu nie może być uregulowana w innych przepisach powszechnie obowiązujących, a po drugie - wprowadzenie określonych norm musi być uzasadnione ze względu na ochronę wartości, o których mowa $\mathrm{w}$ art. 40 ust. 3 u.s.g. ${ }^{19} \mathrm{~W}$ innych przypadkach rada gminy nie może stanowić przepisów porządkowych, nawet jeżeli brak takiej regulacji zagrażałby określonym dobrom.

Upoważnienie dla rady gminy, wynikające z art. 40 ust. 3 u.s.g., nie podlega wykładni rozszerzającej, co oznacza, że przepisy porządkowe mogą być wydawane tylko w wyjątkowych, ściśle określonych przez tę regulację okolicznościach ${ }^{20}$. Zakaz wykładni rozszerzającej wynika z zasady poprawnej legislacji, w świetle której nie należy domniemywać kompetencji prawotwórczych.

Według art. 41 u.s.g., w przypadku niecierpiącym zwłoki, przepisy porządkowe może wydać wójt (burmistrz, prezydent miasta) w formie zarządzenia, które podlega zatwierdzeniu na najbliższej sesji rady gminy. Traci ono moc w razie odmowy zatwierdzenia bądź nieprzedstawienia do zatwierdzenia na najbliższej sesji rady. W przypadku nieprzedstawienia do zatwierdzenia lub odmowy zatwierdzenia zarządzenia rada gminy określa termin utraty jego mocy obowiązującej. Organ wykonawczy gminy przesyła przepisy porządkowe do wiadomości wójtom sąsiednich gmin i staroście powiatu, w którym leży gmina, następnego dnia po ich ustanowieniu $^{21}$. Zasadą jest, że przepisy porządkowe ustanawia rada gminy, jed-

${ }^{18}$ M. Krzyżanowska, Tworzenie aktów prawa miejscowego jako przejaw stosowania prawa przez organy jednostek samorządu terytorialnego, [w:] Tworzenie a stosowanie prawa..., s. 117.

${ }^{19}$ Wyrok WSA z dnia 18 października 2011 roku, II SA/Wr 501/11, LEX nr 1103075.

${ }^{20}$ Wyrok WSA z dnia 8 grudnia 2010 roku, IV SA/Po 793/10, LEX nr 821207.

${ }^{21}$ Art. 41 u.s.g. legitymuje organ monokratyczny w sferze wykonywania funkcji prawotwórczej do wydawania przepisów porządkowych w formie zarządzenia. Są to uprawnienia wyjątkowe, gdyż co do zasady przepisy porządkowe stanowi rada gminy. Zob. P. Dobosz, [w:] Komentarz do ustawy o samorzadzie gminnym, pod red. P. Chmielnickiego, Warszawa 2007, s. 408. Organ wykonawczy gminy może podejmować inicjatywę prawodawczą w zakresie stanowienia przepisów porządkowych, w sytuacjach szczególnych, zagrażających określonym dobrom, gdy zachodzi okoliczność zmuszająca do natychmiastowego działania, a rada gminy nie może niezwłocznie ustanowić przepisów porządkowych. Zob. M. Karpiuk, Miejsce samorządu terytorialnego w przestrzeni bezpie- 
nak status zagrożenia może powodować konieczność podjęcia natychmiastowego działania w tym zakresie, wobec czego stosowne zarządzenie wydaje organ wykonawczy, gdy rada gminy w tak krótkim czasie nie jest w stanie przeprowadzić sesji. Ta kompetencja prawotwórcza wójta (burmistrza, prezydenta miasta) ma charakter „względny” w tym sensie, że przepisy porządkowe wydane przez monokratyczny organ gminy są weryfikowane przez organ stanowiący tej jednostki samorządu terytorialnego.

Do stanowienia przepisów porządkowych uprawniony jest również drugi szczebel samorządu lokalnego - samorząd powiatowy. W zakresie nieuregulowanym w przepisach powszechnie obowiązujących, w szczególnie uzasadnionych przypadkach, rada powiatu może wydawać powiatowe przepisy porządkowe, jeżeli jest to niezbędne do ochrony życia, zdrowia lub mienia obywateli, ochrony środowiska naturalnego bądź do zapewnienia porządku, spokoju i bezpieczeństwa publicznego, o ile przyczyny te występują na obszarze więcej niż jednej gminy. Powiatowe przepisy porządkowe mogą przewidywać za ich naruszenie kary grzywny ${ }^{22}$. Przepis ten przyznaje radzie powiatu kompetencje prawodawcze w bardzo szerokim zakresie przedmiotowym. Wartości uzasadniające stanowienie przepisów porządkowych zostały określone w sposób bardzo ogólny. Tak szeroki zakres upoważnień do stanowienia aktów podustawowych może budzić wątpliwości co do jego zgodności z Konstytucją RP. Z drugiej strony kompetencje te mogą być wykorzystywane wyłącznie wtedy, gdy jest to niezbędne dla ochrony wartości wymienionych w tym przepisie. Kompetencja do stanowienia przepisów porządkowych nie może być wykorzystywana do bieżącego zarządzania na danym obszarze, a wyłącznie w celu przeciwdziałania w szczególnych sytuacjach realnym zagrożeniom dla określonych wartości. Należy przy tym podkreślić, że rada powiatu może stanowić przepisy porządkowe wyłącznie w zakresie nieuregulowanym w ustawach lub innych przepisach powszechnie obowiązujących. Uregulowanie określonej sfery przez ustawodawcę wyklucza stanowienie przepi-

czeństwa narodowego, Warszawa 2014, s. 44. Kompetencje prawodawcze organu wykonawczego gminy wywodzone z art. 41 ust. 2 u.s.g. mają charakter subsydiarny; przysługują, gdy rada gminy niezwłocznie nie może skorzystać z przyznanych jej uprawnień. Zob. idem, Akty prawa miejscowego organów samorządu terytorialnego, [w:] M. Karpiuk, J. Kostrubiec, M. Paździor, K. Popik-Chorąży, K. Sikora, op. cit., s. 117. Wyposażenie egzekutywy w kompetencje do stanowienia przepisów porządkowych ma na celu zapewnienie większej operatywności i szybkości działania w sytuacjach o szczególnym charakterze. Potwierdzają one wyjątkowy charakter norm porządkowych, jak również cel, jaki mają osiągnąć, którym jest przeciwdziałanie nagle pojawiającym się zagrożeniom dóbr prawnie chronionych. Zob. J. Lipski, Akty prawa miejscowego w świetle regulacji prawnych, orzecznictwa i doktryny, Warszawa 2009, s. 45.

${ }^{22}$ Art. 41 ustawy z dnia 5 czerwca 1998 roku o samorządzie powiatowym (t.j. Dz.U. z 2013 roku, poz. 595 ze zm.), dalej: u.s.p. Zob. także: M. Karpiuk, Stanowienie aktów prawa miejscowego przez organy administracji publicznej, [w:] Wpływ prakseologii na organizację i zarzadzanie w administracji publicznej, pod red. K. Sikory, M. Domagały, E. Jasiuk, Radom 2010, s. 39. 
sów porządkowych jej dotyczących na podstawie stosownych upoważnień ustawowych ${ }^{23}$.

Specyficzną cechą przepisów porządkowych jest możliwość ustanowienia sankcji za ich nieprzestrzeganie, która przybiera formę kary grzywny ${ }^{24}$. Do istoty prawa należy możliwość stosowania sankcji w celu zapewnienia jego przestrzegania. Przyznanie organom władzy publicznej kompetencji do stanowienia aktów podustawowych o charakterze powszechnie obowiązującym zakłada stanowienie i wymierzanie kar za naruszenie norm prawnych ustanowionych przez te organy. Powyższe dotyczy w szczególności kompetencji do stanowienia przepisów porządkowych, których celem jest zapewnienie porządku i spokoju publicznego. $\mathrm{Z}$ drugiej strony, według art. 42 ust. 1 Konstytucji RP, określanie czynów zabronionych i kar za te czyny należy do wyłącznej kompetencji ustawodawcy ${ }^{25}$. To on powinien decydować o tym, czy mamy do czynienia z czynem zabronionym pod groźbą kary oraz z odpowiedzialnością karną za ten czyn, terenowy organ administracji publicznej nie powinien posiadać kompetencji w tym zakresie.

Odpowiedzialności za wykroczenie podlega wyłącznie ten, kto popełnia czyn społecznie szkodliwy, który jest zabroniony przez ustawę obowiązującą w czasie jego popełnienia pod groźbą kary. Za taki akt normatywny nie może być uznana uchwała. Może ona stanowić m.in. przepisy porządkowe, jednak należy je traktować jedynie jako normy sankcjonowane (zakazy), których naruszenie może prowadzić do odpowiedzialności wynikającej z k.w., o ile w sposób wyraźny i skonkretyzowany dokonano takiego zastrzeżenia w treści uchwały ${ }^{26}$.

Jak stanowi art. 42 u.s.p., powiatowe przepisy porządkowe, w przypadkach niecierpiących zwłoki, może wydać zarząd i podlegają one zatwierdzeniu na najbliższej sesji rady powiatu. Tracą moc w razie nieprzedłożenia ich do zatwierdzenia lub w przypadku odmowy zatwierdzenia. Termin utraty mocy obowiązującej określa rada powiatu. Starosta przesyła przepisy porządkowe do wiadomości organom wykonawczym gmin położonych na obszarze powiatu i starostom sąsiednich powiatów następnego dnia po ich ustanowieniu ${ }^{27}$. Ustawodawca, pod

${ }^{23}$ Wyrok TK z dnia 8 lipca 2003 roku, P 10/02, OTK ZU 2003, nr 6A, poz. 62.

${ }^{24}$ B. Dolnicki, [w:] Ustawa o samorzadzie powiatowym. Komentarz, pod red. B. Dolnickiego, Warszawa 2007, s. 364.

${ }^{25}$ Wyrok TK z dnia 8 lipca 2003 roku, P 10/02, OTK ZU 2003, nr 6A, poz. 62. Jedną z podstawowych zasad prawa represyjnego jest nullum crimen sine lege poenali anteriori, z której wynika obowiązek określenia znamion czynu zabronionego w ustawie. Zob. M. Czuryk, Stanowienie aktów prawa miejscowego przez organy samorzadu terytorialnego szczebla lokalnego i regionalnego, [w:] Akty normatywne..., s. 134.

${ }^{26}$ Wyrok SN z dnia 20 października 2009 roku, III KK 249/09, LEX nr 529597.

${ }^{27}$ Organ wykonawczy wydaje przepisy porządkowe wyłącznie w sytuacji, gdy rada powiatu nie może rozstrzygnąć w tym przedmiocie. Zob. M. Karpiuk, Status prawny organów samorzadu terytorialnego w sferze bezpieczeństwa publicznego, [w:] Prawo bezpieczeństwa publicznego, pod red. M. Karpiuka, K. Walczuka, Warszawa 2013, s. 111. 
szczególnymi warunkami, przyznaje kompetencję prawodawczą w zakresie stanowienia przepisów porządkowych organowi wykonawczemu powiatu. Zarząd wydaje takie przepisy, gdy rozwój sytuacji (zagrożenia) powoduje, że istnieje bezzwłoczna konieczność ustanowienia tego rodzaju regulacji. Potrzebę tę weryfikuje następnie na najbliższej sesji rada powiatu. Przepisy te muszą być zatwierdzone przez organ stanowiący, jest to wymóg ustawowy, przy czym art. 42 u.s.p. nie wprowadza przesłanek tej weryfikacji, co nie zwalnia rady powiatu od zbadania istnienia warunków przewidzianych w art. 41 u.s.p.

Kompetencje $\mathrm{w}$ zakresie stanowienia samorządowych przepisów porządkowych zawierają również ustawy materialne. W odniesieniu do gminnego regularnego przewozu osób oraz przewozów osób i bagażu taksówkami przepisy porządkowe określa rada gminy, a na terenie miasta stołecznego Warszawy rada miasta stołecznego Warszawy. W odniesieniu do powiatowego regularnego przewozu osób przepisy porządkowe określa rada powiatu, a w odniesieniu do wojewódzkiego regularnego przewozu osób - sejmik województwa. Rada gminy (rada miasta stołecznego Warszawy) może wprowadzić obowiązek stosowania dodatkowych oznaczeń i dodatkowego wyposażenia technicznego w odniesieniu do taksówek ${ }^{28}$. Przepisy porządkowe w sferze przewozu osób stanowią organy stanowiące samorządu terytorialnego, ustawodawca nie przewidział delegacji tej kompetencji prawodawczej na egzekutywę.

\section{OGŁASZANIE PRZEPISÓW PORZĄDKOWYCH}

Ogłoszenie aktu normatywnego w dzienniku urzędowym ma charakter obowiązkowy ${ }^{29}$. Zasadą jest zatem obowiązek ogłaszania aktów normatywnych we właściwym dzienniku urzędowym. W związku z powyższym przepisy porządkowe, jako akty prawa miejscowego, podlegają ogłoszeniu w wojewódzkim dzienniku urzędowym prowadzonym przez wojewodę. Zwolnienie $\mathrm{z}$ tego obowiązku może nastąpić wyłącznie na mocy ustawowych przepisów szczególnych.

Przepisy porządkowe wchodzą w życie po upływie trzech dni od dnia ich ogłoszenia, jednak w uzasadnionych przypadkach mogą wchodzić w życie w terminie krótszym niż trzy dni, a w przypadku, gdy zwłoka w wejściu w życie przepisów porządkowych mogłaby spowodować nieodwracalne szkody lub poważne zagrożenia życia, zdrowia lub mienia, można zarządzić wejście w życie takich przepisów z dniem ich ogłoszenia, o czym stanowi art. 4 ust. 3 u.o.a.n. Zasadą jest trzydniowy okres vacatio legis przewidziany dla przepisów porządkowych (dla pozostałych aktów normatywnych, zawierających przepisy powszechnie obowią-

${ }^{28}$ Art. 15 ust. 5-7 ustawy z dnia 15 listopada 1984 roku - Prawo przewozowe (t.j. Dz.U. z 2012 roku, poz. 1173 ze zm.).

${ }^{29}$ Art. 2 ust. 1 ustawy z dnia 20 lipca 2000 roku o ogłaszaniu aktów normatywnych i niektórych innych aktów prawnych (t.j. Dz.U. z 2011 roku, nr 197, poz. 1172 ze zm.), dalej: u.o.a.n. 
zujące, z reguły jest to 14 dni). Jednak ustawodawca dopuszcza w „uzasadnionych przypadkach" krótszy niż trzydniowy termin przewidziany dla wejścia w życie przepisów porządkowych. $Z$ dniem ogłoszenia mogą wejść w życie wyłącznie te przepisy porządkowe, których zwłoka w wejściu w życie mogłaby spowodować nieodwracalne szkody bądź poważne zagrożenie wartości określonych w art. 4 ust. 3 u.o.a.n.

Według art. 14 u.o.a.n. przepisy porządkowe ogłasza się w drodze obwieszczeń, a także w sposób zwyczajowo przyjęty na danym terenie ${ }^{30}$ lub w środkach masowego przekazu. Za dzień ogłoszenia przepisów porządkowych uważa się dzień wskazany w obwieszczeniu. Ogłoszenie w powyższy sposób nie zwalnia z obowiązku ogłoszenia przepisów porządkowych w wojewódzkim dzienniku urzędowym. Przepisy porządkowe, obok obowiązkowej publikacji w wojewódzkim dzienniku urzędowym, ogłaszane są również w drodze obwieszczeń oraz w sposób przyjęty zwyczajowo na określonym obszarze, ewentualnie w środkach masowego przekazu. Proces publikacji przepisów porządkowych jest sformalizowany i wymaga wielopłaszczyznowego działania - publikator urzędowy, obwieszczenia, ogłoszenia zwyczajowe, ewentualnie w mediach. Przyjęcie takiego trybu jest związane z potrzebą zapoznania się z treścią przepisów porządkowych możliwie jak najszerszego grona adresatów tych norm w możliwie jak najkrótszym czasie.

\section{BIBLIOGRAFIA}

Banaszak B., Konstytucja Rzeczypospolitej Polskiej. Komentarz, Warszawa 2009.

Czuryk M., Akty prawa miejscowego organów rzadowej administracji niezespolonej, [w:] Niezespolona administracja rzadowa, pod red. M. Czuryk, M. Karpiuka, J. Kostrubca, Warszawa 2011.

Czuryk M., Stanowienie aktów prawa miejscowego przez organy samorządu terytorialnego szczebla lokalnego i regionalnego, [w:] Akty normatywne i administracyjne, pod red. M. Karpiuka, Warszawa 2009.

Dobosz P., [w:] Komentarz do ustawy o samorzadzie gminnym, pod red. P. Chmielnickiego, Warszawa 2007.

Dolnicki B., [w:] Ustawa o samorzadzie powiatowym. Komentarz, pod red. B. Dolnickiego, Warszawa 2007.

Karpiuk M., Akty prawa miejscowego organów samorządu terytorialnego, [w:] M. Karpiuk, J. Kostrubiec, M. Paździor, K. Popik-Chorąży, K. Sikora, Legislacja administracyjna, Warszawa 2013.

Karpiuk M., Działalność prawodawcza administracji rzadowej, [w:] Akty normatywne i administracyjne, pod red. M. Karpiuka, Warszawa 2009.

\footnotetext{
${ }^{30}$ Ogłoszenie w sposób zwyczajowo przyjęty w danej gminie oznacza wywieszenie informacji na tablicach ogłoszeń w urzędzie gminy oraz we wszystkich sołectwach na obszarze gminy. Po rozpowszechnieniu informacji elektronicznej rangę taką otrzymała również strona internetowa gminy, a także Biuletyn Informacji Publicznej danej gminy. Zob. wyrok WSA z dnia 16 kwietnia 2014 roku, II SA/Sz 281/14, LEX nr 1460318.
} 
Karpiuk M., Miejsce samorządu terytorialnego w przestrzeni bezpieczeństwa narodowego, Warszawa 2014.

Karpiuk M., Stanowienie aktów prawa miejscowego przez organy administracji publicznej, [w:] Wpływ prakseologii na organizację i zarzadzanie w administracji publicznej, pod red. K. Sikory, M. Domagały, E. Jasiuk, Radom 2010.

Karpiuk M., Status prawny organów samorząu terytorialnego $w$ sferze bezpieczeństwa publicznego, [w:] Prawo bezpieczeństwa publicznego, pod red. M. Karpiuka, K. Walczuka, Warszawa 2013.

Krzyżanowska M., Tworzenie aktów prawa miejscowego jako przejaw stosowania prawa przez organy jednostek samorzadu terytorialnego, [w:] Tworzenie a stosowanie prawa w Polsce. Teoria i praktyka, pod red. D. Kotłowskiego, M. Mazuryka, K. Sadowskiego, Warszawa 2014.

Lipski J., Akty prawa miejscowego w świetle regulacji prawnych, orzecznictwa i doktryny, Warszawa 2009.

Sikora K., Akty prawa miejscowego terenowych organów administracji rzadowej, [w:] M. Karpiuk, J. Kostrubiec, M. Paździor, K. Popik-Chorąży, K. Sikora, Legislacja administracyjna, Warszawa 2013.

Walczuk K., [w:] Ustawa o wojewodzie i administracji rządowej w województwie. Komentarz, pod red. M. Czuryk, M. Karpiuka, M. Mazuryka, Warszawa 2012.

Walczuk K., Rozporzadzenie porzadkowe jako akt prawa miejscowego, [w:] Tworzenie a stosowanie prawa w Polsce. Teoria i praktyka, pod red. D. Kotłowskiego, M. Mazuryka, K. Sadowskiego, Warszawa 2014.

Winczorek P., Komentarz do Konstytucji Rzeczypospolitej Polskiej z dnia 2 kwietnia 1997 roku, Warszawa 2008.

\section{SUMMARY}

Regulations belong to the catalogue of the sources of common law, forcefully shaping the status of the recipient. The scope of regulations established within the structure of local law refers to an area where the authority establishing a given act performs its competence. These regulations are executive in character, and the issuing authorization must be included in the act. A public administration body cannot therefore form the legal status of the recipient if the legislator does not allow it.

Keywords: sources of common law; public administration body 